\title{
Intake of dairy products and risk of colorectal neoplasia
}

\author{
Maria Pufulete* \\ Diet and Gastrointestinal Health Group, Nutritional Sciences Division, King's College London, 150 Stamford Street, \\ London SE1 9NH, UK
}

\begin{abstract}
Prospective cohort studies suggest that higher intakes of dairy products, in particular milk, are associated with a decreased risk of colorectal cancer (CRC). In Western populations, dairy products are major contributors to dietary $\mathrm{Ca}$, which may have chemopreventive effects in the colon. The pooling of data from prospective studies suggests a significant protective effect of $\mathrm{Ca}$ on CRC risk. Randomised controlled trials with Ca supplements have been conducted with both colorectal adenoma and CRC as endpoints. Results suggest that $\mathrm{Ca}$ supplementation at a level of $1000-2000 \mathrm{mg} / \mathrm{d}$ reduces adenoma recurrence in individuals with a previous adenoma but has no effect on CRC incidence. There is evidence that the risk reduction from dairy foods may not be solely due to their high Ca content. Dairy products contain other potential chemopreventive components such as vitamin D, butyric acid, conjugated linoleic acid, sphingolipids, and probiotic bacteria in fermented products such as yoghurt. The present review will focus on the epidemiological evidence (and in particular prospective cohort studies) investigating the relationship between dairy product consumption and risk of CRC. An outline of the proposed mechanisms responsible for the protective effect of both $\mathrm{Ca}$ and other potential chemopreventive components in dairy products will also be presented.
\end{abstract}

Dairy products: Colorectal cancer: Adenoma: Calcium: Vitamin D

\section{Introduction}

In the UK, colorectal cancer (CRC) affects about 35000 individuals each year ${ }^{(1)}$. It is the second most common cancer in women (after breast cancer) and the third most common cancer in men (after prostate and lung cancer) ${ }^{(1)}$. About 16000 individuals each year die from CRC, making it the second most common cause of death from cancer ${ }^{(1)}$. Worldwide, CRC is the third most common cancer after breast and lung cancer, with the highest rates in areas such as Australia, New Zealand and Western Europe and the lowest rates in regions such as Africa and Asia ${ }^{(2)}$. Immigrants rapidly acquire the incidence rates of the host country, suggesting that environmental factors play a crucial role in CRC development ${ }^{(3)}$.

$\mathrm{CRC}$ is an age-related disease, with half of all cases occurring in individuals aged over 60 years ${ }^{(1)}$. The disease is believed to arise from benign tumours called adenomatous polyps (adenomas). Although incidence of adenoma is difficult to predict, necropsy studies show a prevalence of about $35 \%$ in European populations ${ }^{(4)}$. About $1-10 \%$ of adenomas go on to develop into invasive cancer ${ }^{(5)}$. Genetic predisposition plays a role in about $15 \%$ of $\mathrm{CRC}^{(6)}$ but most cases are sporadic. It has been estimated that about $70 \%$ of CRC can be prevented by changes in diet and lifestyle ${ }^{(7)}$.
Factors known to increase risk include age, obesity, physical inactivity, and tobacco and alcohol use ${ }^{(8)}$. Generally populations with 'Westernised' diets high in red meat and fat and low in fruit, vegetables and dietary fibre are at higher risk $^{(8)}$. These populations also tend to have a higher proportion of overweight individuals and lower levels of physical activity ${ }^{(8)}$.

Of the many dietary factors that have been investigated for a potential link with CRC risk, none are more diverse in terms of composition, factors that could potentially influence cancer risk and multiple mechanisms through which these factors could act than dairy products. For example, whole milk and many types of cheese have a relatively high fat content, which may increase the risk of colorectal adenoma and cancer ${ }^{(9,10)}$. However, dairy products also have high $\mathrm{Ca}$ and vitamin $\mathrm{D}$ contents, which have been linked to a reduced risk of $\mathrm{CRC}^{(11,12)}$.

Dairy products are important components of the human diet. In the UK they contribute $10 \%$ of the average daily energy intake in the diet of adults ${ }^{(13)}$ and also contribute significantly to the average daily intakes of vitamins such as riboflavin (33\%), vitamin $\mathrm{B}_{12}(36 \%)$ and vitamin $\mathrm{D}(3 \%)$, and minerals such as $\mathrm{Ca}(43 \%), \mathrm{P}(24 \%)$ and $\mathrm{Mg}(11 \%)^{(14)}$. The present review will focus on the current epidemiological evidence investigating the relationship between

Abbreviations: CLA, conjugated linoleic acid; CRC, colorectal cancer; RR, relative risk.

* Corresponding author: Dr Maria Pufulete, fax +44 207848 4185, email maria.pufulete@kcl.ac.uk 
dairy product consumption and risk of CRC. An outline of the proposed mechanisms responsible for the observed relationship will also be presented.

\section{Epidemiological studies of dairy products and colorectal cancer risk}

A large number of prospective cohort and case-control studies have investigated the link between dairy foods and $\mathrm{CRC}$ risk. One of the problems with assessing the evidence is the considerable variation in how consumption data were collected, with some studies reporting overall dairy product consumption, while others report categories such as milk, butter, cheese and fermented milk products. Generally, results from case-control studies are heterogeneous and do not provide evidence of an association between total intake of dairy products and CRC risk ${ }^{(15)}$. Because of the abundance of prospective studies that have investigated the relationship between dairy intake and risk of CRC and because results from case-control studies have been reviewed in detail elsewhere ${ }^{(15)}$, the present review will focus mainly on prospective studies. The prospective studies ${ }^{(12,16-39)}$ that have assessed the relationship between dairy foods and CRC risk are summarised in Table 1. Data from these studies point to an inverse association, although generally the relationships are statistically non-significant. However, two recent studies, the Cohort of Swedish Men ${ }^{(38)}$ and the US Multiethnic Cohort Study ${ }^{(12)}$, have shown significant reduction in risk ( 54 and $20 \%$, respectively) with the highest intake of total dairy products.

Milk is the dairy product that shows the most consistent relationship with CRC risk. Of the cohort studies to date that have investigated this relationship, most showed nonsignificant decreased risks of CRC with increasing milk intake ${ }^{(12,17,19,22,23,27,29,30,33,34,38)}$. Most studies have considered all types of milk together, but where these have been separated there are differences between low-fat $v$. whole milk. In the US study on an Adventist population, consumption of skimmed milk, but not whole milk, had a protective effect (relative risk (RR) 0.78 for skimmed milk v. RR 1.04 for whole milk) ${ }^{(27)}$. A few case-control studies (reviewed by Norat \& Riboli ${ }^{(15)}$ ) have shown similar trends although none of the relationships were statistically significant. In a recent case-control study, whole milk consumption was positively associated with cancer of the rectum (OR 1.22; $95 \%$ CI 1.03, 1.44) while skimmed milk consumption was inversely associated with cancers of the colon (OR 0.84; $95 \%$ CI 0.73, 0.97) and rectum (OR 0.76; $95 \%$ CI 0.64, 0.91 $)^{(40)}$. However, further studies are required to determine any effect of milk fat on CRC risk.

The pooling of data from prospective studies has revealed significant relationships between milk intake and CRC risk. Norat \& Riboli ${ }^{(15)}$ analysed data from eleven cohorts and showed a RR of 0.80 (95\% CI 0.68, 0.95) for the highest $v$. the lowest milk intake. Similarly, Cho et al. ${ }^{(11)}$ analysed data from ten cohorts from five countries, including 534536 individuals, of whom 4992 were diagnosed with CRC at follow-up. A significant protective effect of milk was found; individuals that consumed more than a glass of milk per $\mathrm{d}(\geq 250 \mathrm{~g})$ had a $15 \%$ reduced risk of developing CRC (RR $0.85 ; 95 \%$ CI $0.78,0.94)$ compared with those that consumed $<70 \mathrm{~g} / \mathrm{d}$. Each $500 \mathrm{~g} / \mathrm{d}$ increase in milk intake reduced the risk of CRC by $12 \%$ (RR 0.88; $95 \%$ CI 0.82 , 0.95). The inverse association was consistent across studies and sex. The main strength of this meta-analysis is the pooling of individual level prospective data. All included studies used validated diet assessment methods, minimising the possibility of an incorrect recording of the actual intake of dairy products. However, although Cho et al. ${ }^{(11)}$ adjusted the multivariable RR for energy, alcohol, red meat and dietary folate intakes, they did not adjust for other dietary variables related to $\mathrm{CRC}$ risk, such as dietary fibre and fruit and vegetable intakes; therefore it is possible that some residual confounding remains.

Data for other dairy products generally do not support a protective effect against CRC. In the meta-analysis by Cho et al. (11) dairy foods such as cottage or ricotta cheese, butter, cream and ice cream (which were measured in at least five out of the ten studies) also showed inverse associations with CRC risk, although results were not statistically significant. Data on fermented milk products such as yoghurt suggest no relationship with $\mathrm{CRC}$ risk $^{(22,23,30,38)}$. For cheese intake, RR range from 0.68 to 1.35 and in most studies the RR was greater than $1 \cdot 0$, although none of these relationships were statistically significant $^{(17,22,23,27,30,34,38)}$. Some studies ${ }^{(27,38)}$ have attempted to separate hard cheese from soft cheeses such as ricotta and cottage cheese, with the latter appearing to have a protective effect; however, the relationships were not significant and it is difficult to draw any reasonable conclusions from such few studies. A recent meta-analysis on three cohort studies ${ }^{(23,27,37)}$ conducted for the second expert report on diet and the prevention of cancer ${ }^{(8)}$ showed a RR of $1.14(95 \%$ CI $0.82,1.58)$ per serving of cheese per $\mathrm{d}$, with low heterogeneity, although it is not clear which kind of cheese was included in the analysis. The Panel concluded that there is some (albeit limited) evidence that cheese is a cause of $\mathrm{CRC}^{(8)}$. Cheese is high in saturated fats, which have been shown to increase insulin production and expression of insulin on colonic cells ${ }^{(41)}$. Saturated fats may also induce the expression of some inflammatory mediators associated with the cancer process ${ }^{(42)}$. However, it is difficult to reconcile this with data on the protective effects of dietary $\mathrm{Ca}$, which is abundant in cheese ${ }^{(43)}$.

Although there are inconsistencies between studies, most of the evidence points to a decreased risk of CRC with increasing intake of $\mathrm{Ca}$, both dietary and total (including supplements $)^{(12,24,28,31,32,35,36)}$. Several meta-analyses have quantified the relationship between $\mathrm{Ca}$ intake and $\mathrm{CRC}$ risk $^{(8,11,44)}$. An early meta-analysis of eight cohort and sixteen case-control studies showed that the highest category of $\mathrm{Ca}$ intake was associated with a $14 \%$ decrease in risk of $\mathrm{CRC}$, although there was considerable heterogeneity between studies, which made reaching a conclusion difficult ${ }^{(44)}$. In the meta-analysis by Cho et al. ${ }^{(11)}$ individuals consuming the highest category of dietary $\mathrm{Ca}$ had a significantly lower risk of developing CRC (RR 0.86; $95 \%$ CI $0.78,0.95)$. A meta-analysis on ten cohort studies conducted for the second expert report on diet and the prevention of cancer ${ }^{(8)}$ showed a RR of 0.98 (95\% CI 0.95, $1.00)$ per $200 \mathrm{mg} / \mathrm{d}$, with low heterogeneity. Both metaanalyses suggested a threshold effect of Ca intake; no further protection was observed at intakes $>1000 \mathrm{mg} / \mathrm{d}$. 


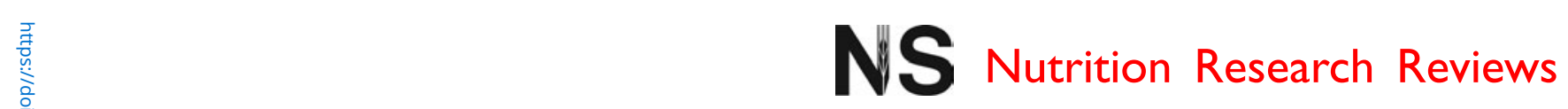

Table 1. Prospective studies of dairy and/or dietary calcium and vitamin D intake and risk of colorectal cancer (CRC)

\begin{tabular}{|c|c|c|c|c|c|c|c|}
\hline Study & Location & Endpoint & Cohort size/number of cases & $\begin{array}{l}\text { Follow-up } \\
\text { (years) }\end{array}$ & Dairy products evaluated* & $\mathrm{RR} \dagger$ & $95 \% \mathrm{Cl}$ \\
\hline Phillips $(1975)^{(16)}$ & USA & CRC mortality & $\begin{array}{l}35460 \text { (number of CRC } \\
\text { cases not given) }\end{array}$ & 8 & Milk (<one serving per $\mathrm{d} v$. > one serving per $\mathrm{d}$ ) & 0.3 & \\
\hline \multirow{2}{*}{$\begin{array}{l}\text { Phillips \& Snowdon } \\
\qquad(1985)^{(17)}\end{array}$} & \multirow[t]{2}{*}{ USA } & \multirow[t]{2}{*}{ CRC mortality } & 25493/182 & \multirow[t]{2}{*}{20} & Milk (<one $v$. $\geq$ three glasses per $d$ ) & 0.9 & $0.6,1.5$ \\
\hline & & & Seventh-Day Adventists & & Cheese $(<1 v . \geq 3 \mathrm{~d} /$ week $)$ & $1 \cdot 1$ & $0.8,1.6$ \\
\hline $\begin{array}{l}\text { Garland et al. } \\
\quad(1985)^{(18)}\end{array}$ & USA & CRC incidence & $1954 / 100$ & 19 & $\begin{array}{l}\text { Combined index of dietary } \mathrm{Ca} \text { and vitamin } \mathrm{D} \\
\text { (lowest } v \text {. highest) }\end{array}$ & $\begin{array}{l}\text { Lowest } 38 \cdot 9 / 1000 \\
\text { population } \\
\text { Highest } 14 \cdot 3 / 1000 \\
\text { population }\end{array}$ & \\
\hline Ursin et al. (1990) ${ }^{(19)}$ & Norway & CRC incidence & $15914 / 155$ & 11.5 & Milk ( $\geq$ two glasses $v$. <one glass per d) & 0.85 & \\
\hline Thun et al. (1992) ${ }^{(20)}$ & USA & CRC mortality & $1185124 / 2757$ & 2 & $\begin{array}{l}\text { Butter, cheese, whole milk, ice cream and } \\
\text { eggs (lowest } v \text {. highest quintile of intake) }\end{array}$ & $\begin{array}{l}1.05 \text { (men) } \\
0.96 \text { (women) }\end{array}$ & \\
\hline \multirow[t]{3}{*}{$\begin{array}{l}\text { Bostick et al. } \\
\qquad(1993)^{(21)}\end{array}$} & \multirow[t]{3}{*}{ USA } & \multirow[t]{3}{*}{$\begin{array}{l}\text { Colon cancer } \\
\text { incidence }\end{array}$} & $\begin{array}{l}35215 / 212 \\
\text { Women's Health Study }\end{array}$ & \multirow[t]{3}{*}{4} & $\begin{array}{l}\text { Total dairy (<eight } v \text {. }>\text { twenty-five servings per week) } \\
\text { Fat-containing dairy products }(<\text { four } v \text {. }>\text { fourteen } \\
\text { servings per week) }\end{array}$ & $\begin{array}{l}0.72 \\
0.78\end{array}$ & $\begin{array}{l}0.38,1.36 \\
0.45,1.36\end{array}$ \\
\hline & & & & & Dietary $\mathrm{Ca}(<496 v .>1186 \mathrm{mg} / \mathrm{d})$ & 0.95 & $0.57,1.61$ \\
\hline & & & & & Dietary vitamin $\mathrm{D}(<127 v .>373 \mathrm{IU} / \mathrm{d}) \ddagger$ & 0.98 & $0.61,1.58$ \\
\hline \multirow{6}{*}{$\begin{array}{l}\text { Kampman et al. } \\
\qquad(1994)^{(22)}\end{array}$} & \multirow[t]{6}{*}{ Holland } & \multirow[t]{6}{*}{ CRC incidence } & $120852 / 312$ & \multirow[t]{6}{*}{$3 \cdot 3$} & Milk (non-users v. >240 g/d) & 0.86 & $0.57,1.29$ \\
\hline & & & & & Buttermilk and yoghurt (non-users $v . \geq 180 \mathrm{~g} / \mathrm{d}$ ) & 0.89 & $0.60,1.33$ \\
\hline & & & & & Hard cheese (non-users $v . \geq 30 \mathrm{~g} / \mathrm{d}$ ) & 0.88 & $0.59,1.33$ \\
\hline & & & & & Total dietary $\mathrm{Ca}(596$ v. $1288 \mathrm{mg} / \mathrm{d})$ & 0.90 & $0.64,1.34$ \\
\hline & & & & & Ca from unfermented products $(45 \mathrm{v} .540 \mathrm{mg} / \mathrm{d})$ & 0.71 & $0.48,1.05$ \\
\hline & & & & & Ca from fermented products $(64 \mathrm{v} .634 \mathrm{mg} / \mathrm{d})$ & $1 \cdot 14$ & $0.77,1.68$ \\
\hline \multirow[t]{6}{*}{$\begin{array}{l}\text { Kearney et al. } \\
\qquad(1996)^{(23)}\end{array}$} & \multirow[t]{6}{*}{ USA } & \multirow[t]{6}{*}{$\begin{array}{l}\text { Colon cancer } \\
\text { incidence }\end{array}$} & $\begin{array}{l}\text { 47935/203 } \\
\text { Health Professionals }\end{array}$ & \multirow[t]{6}{*}{6} & $\begin{array}{l}\text { Milk (<one } 8 \text { oz glass per month } v \text {. five } \\
\text { to seven } 8 \text { oz glasses per week) }\end{array}$ & 0.72 & $0.45,1.15$ \\
\hline & & & Follow-Up Study & & $\begin{array}{l}\text { Ice cream ( } 4 \text { ounce serving: } \\
\quad<\text { one per month } v \text {. > one per d) }\end{array}$ & 0.93 & $0.42,2.04$ \\
\hline & & & & & $\begin{array}{l}\text { Hard cheese ( } 1 \text { ounce serving: } \\
\quad<\text { one per month } v \text {. > one per d) }\end{array}$ & 1.35 & $0.67,2.75$ \\
\hline & & & & & $\begin{array}{l}\text { Fermented dairy products (median } \\
\text { intake }<\text { one per month } v \text {. > one per d) }\end{array}$ & 1.09 & $0.70,1.72$ \\
\hline & & & & & Ca dairy products $(<137 \mathrm{v} . \geq 620 \mathrm{mg} / \mathrm{d})$ & 0.68 & $0.42,1.09$ \\
\hline & & & & & Vitamin D dairy products $(<22 v . \geq 154 \mathrm{IU} / \mathrm{d}) \S$ & 0.75 & $0.47,1.22$ \\
\hline \multirow{3}{*}{$\begin{array}{l}\text { Martinez et al. } \\
\quad(1996)^{(24)}\end{array}$} & USA & CRC incidence & $89448 / 501$ & 12 & Dietary $\mathrm{Ca}(<500 \mathrm{v} .>1000 \mathrm{mg} / \mathrm{d})$ & 0.74 & $0.36,1.50$ \\
\hline & & & Nurses' Health Study & & Dietary vitamin $\mathrm{D}(<85 \mathrm{v} .>280 \mathrm{IU} / \mathrm{d}) \|$ & 0.72 & $0.34,1.54$ \\
\hline & & & & & Total vitamin $\mathrm{D}(<120 \mathrm{v} .>550 \mathrm{IU} / \mathrm{d})$ q & 0.42 & $0.19,0.91$ \\
\hline Kato et al. $(1997)^{(25)}$ & USA & CRC incidence & $\begin{array}{l}15785 / 100 \\
\text { New York University } \\
\text { Women's Health Study }\end{array}$ & $7 \cdot 1$ & $\begin{array}{l}\text { Dairy products, quartiles of intake } \\
\text { (lowest } v \text {. highest) }\end{array}$ & $0.69(P=0.04$ for trend $)$ & $0.40,1 \cdot 20$ \\
\hline Hsing et al. (1998) $)^{(26)}$ & USA & CRC mortality & $\begin{array}{l}\text { 286731/145 } \\
\text { Lutheran Brotherhood Cohort }\end{array}$ & 20 & Dairy products (times per month: $<26 \mathrm{v} .>85$ ) & 0.6 & $0 \cdot 3,1 \cdot 2$ \\
\hline Singh \& Fraser & USA & CRC incidence & $32051 / 157$ & 6 & Whole milk (never $v$. $\geq$ one serving per week) & 1.04 & $0.69,1.59$ \\
\hline$(1998)^{(27)}$ & & & Adventist Health Study & & Low-fat milk (never $v$. $\geq$ one serving per week) & 0.97 & $0.66,1.42$ \\
\hline & & & & & Non-fat milk (never $v$. $\geq$ one serving per week) & 0.78 & $0.48,1.28$ \\
\hline & & & & & Non-cottage cheese (never $v$. $\geq$ one serving per week) & 1.31 & $0.84,2.03$ \\
\hline & & & & & Cottage cheese (never $v . \geq$ one serving per week) & 0.74 & $0.49,1 \cdot 11$ \\
\hline Zheng et al. & USA & Rectal cancer & $34702 / 144$ & 9 & $\mathrm{Ca}\left(<801 v_{.}>1279 \mathrm{mg} / \mathrm{d}\right)$ & 0.59 & $0.37,0.94$ \\
\hline$(1998)^{(28)}$ & & incidence & lowa Women's Health Study & & Vitamin $D(<224 v .>476 \mathrm{IU} / \mathrm{d})^{\star \star}$ & 0.76 & $0.50,1 \cdot 16$ \\
\hline Pietinen et al. & Finland & CRC incidence & $27111 / 185$ & 8 & Milk products $(318 \mathrm{v} .1089 \mathrm{~g} / \mathrm{d})$ & 0.6 & $0.4,0.9$ \\
\hline$(1999)^{(29)}$ & & & $\begin{array}{l}\text { ATBC Prevention Study } \\
\text { (male smokers) }\end{array}$ & & Soured milk products $(0 \mathrm{v} .350 \mathrm{~g} / \mathrm{d})$ & $1 \cdot 1$ & $0.7,1.3$ \\
\hline
\end{tabular}


The evidence for Ca suggests that the protective effect of milk or total dairy may be due in part to its $\mathrm{Ca}$ content, since dietary $\mathrm{Ca}$ can be considered a marker of dairy intake in populations that consume high amounts of milk and dairy products ${ }^{(45)}$. Most of the published cohort studies are from dairy-consuming countries such as the USA, Holland, Finland and Sweden, so it is reasonable to assume that a large proportion of dietary $\mathrm{Ca}$ comes from dairy products. Recent data from the ongoing Cohort of Swedish Men trial $^{(38)}$, a high-quality study established in 1997 to study lifestyle-disease interactions, also reported a decrease in risk of CRC (RR 0.68; $95 \%$ CI 0.51, 0.91) in subjects with the highest $\mathrm{Ca}$ intake. This study also confirmed previous findings that milk was the individual dairy food with the strongest influence on risk but the analysis provided some evidence that the risk reduction from dairy foods may not be solely due to their high $\mathrm{Ca}$ content ${ }^{(38)}$. First, $\mathrm{Ca}$ and total dairy consumption had different effects on risk when the various parts of the colon were considered; for example, $\mathrm{Ca}$ reduced the risk for the rectum while total dairy intake reduced the risk for the proximal colon, distal colon and rectum ${ }^{(38)}$. Second, even though $\mathrm{Ca}$ intake was closely associated with total dairy or milk intake, when the analysis was controlled for $\mathrm{Ca}$ intake, the influence of milk or dairy intake on risk was diminished but not eliminated ${ }^{(38)}$. These findings suggest that other milk-associated factors may be partially responsible for the protective effects and these will be reviewed under the section on mechanisms.

\section{Epidemiological studies of calcium and dairy products and adenoma risk}

Most case-control studies on colorectal adenoma risk have investigated intake of dietary and supplemental $\mathrm{Ca}$ rather than individual dairy products ${ }^{(46-51)}$. OR for these studies range from $0.50-0.97$ and most do not reach statistical significance $^{(47-49,51)}$ although some do show a protective effect of $\mathrm{Ca}^{(46,50)}$. In some studies the protective effect of $\mathrm{Ca}$ was present in men but not in women ${ }^{(47)}$. In other studies the protective effects was mainly due to Ca supplement use; for example, Peters et al. ${ }^{(50)}$ found a decrease in adenoma risk for subjects taking $1200 \mathrm{mg} \mathrm{Ca} / \mathrm{d}$ compared with nonusers (OR 0.74; $95 \%$ CI 0.58, 0.95), after adjustment for vitamin supplement intake as well as other confounders associated with supplement use. Similarly, high $\mathrm{Ca}$ $(>900 \mathrm{mg} / \mathrm{d})$ and lower fat intakes $(<34 \%$ of energy intake) were also reported to protect against colorectal adenomas in a US population, an effect that was not observed with high $\mathrm{Ca}$ and higher fat intakes $(\geq 34 \% \text { of energy intake })^{(51)}$.

Prospective studies ${ }^{(36,52-56)}$ that have investigated $\mathrm{Ca}$ intakes in relation to adenoma risk are listed in Table 2. Martinez et al. ${ }^{(54)}$ showed that intake above $1068 \mathrm{mg} / \mathrm{d} v$. intake below $698 \mathrm{mg} / \mathrm{d}$ was associated with a significant reduction in adenoma recurrence among 1304 male and female participants in the Wheat Bran Fiber trial ofadenoma recurrence $(\mathrm{OR} 0.56 ; 95 \%$ CI $0.39,0.80 ; P$ trend $=0.007)$ and dietary $\mathrm{Ca}$ was found to be more protective than supplemental Ca. Kampman et al. ${ }^{(52)}$ used data from the Health Professionals Follow-Up Study and the Nurses' Health Study and showed no relationship between a high total $\mathrm{Ca}$ intake or dietary $\mathrm{Ca}$ intake and risk of adenoma. 


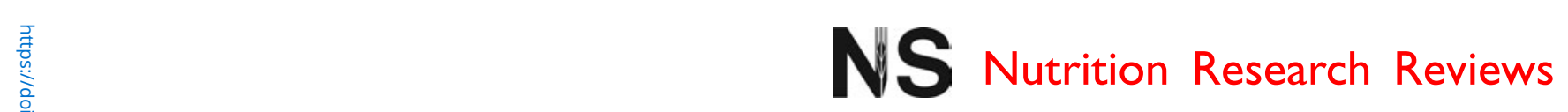

Table 2. Prospective studies of dairy and/or calcium and vitamin D intake and risk of colorectal adenoma

\begin{tabular}{|c|c|c|c|c|c|c|c|}
\hline Study & Location & Endpoint & $\begin{array}{l}\text { Cohort }>\text { size/number } \\
\text { of cases }\end{array}$ & $\begin{array}{l}\text { Follow-up } \\
\text { (years) }\end{array}$ & Dairy products evaluated ${ }^{*}$ & $\mathrm{RR}+$ & $95 \% \mathrm{Cl}$ \\
\hline \multirow[t]{12}{*}{ Kampman et al. (1994) $)^{(52)}$} & \multirow[t]{12}{*}{ USA } & \multirow[t]{12}{*}{$\begin{array}{l}\text { Adenoma } \\
\text { incidence }\end{array}$} & $\begin{array}{l}\text { 9159/331 (Men) } \\
\text { Health Professionals }\end{array}$ & \multirow[t]{6}{*}{4} & $\begin{array}{l}\text { Whole milk (one } 8 \text { ounce glass: almost never } \\
\qquad .>\text { one per d) }\end{array}$ & 0.94 & $0.38,2.34$ \\
\hline & & & \multirow[t]{5}{*}{ Follow-Up Study } & & $\begin{array}{l}\text { Skimmed milk (one } 8 \text { ounce glass: almost never } \\
\quad v \text {. }>\text { one per d) }\end{array}$ & 1.02 & $0.70,1.49$ \\
\hline & & & & & Fermented dairy products $(4 v .111 \mathrm{~g} / \mathrm{d})$ & $1 \cdot 10$ & $0.75,1.62$ \\
\hline & & & & & $\begin{array}{l}\text { Hard cheese ( } 1 \text { ounce serving: < three per month } \\
\quad v .>\text { one per } d)\end{array}$ & 1.45 & $1 \cdot 02,2 \cdot 05$ \\
\hline & & & & & Total Ca intake (mg/d 547 v. 1649) & $1 \cdot 13$ & $0.76,1.66$ \\
\hline & & & & & Dietary vitamin $D(118 v .954 \mathrm{IU} / \mathrm{d}) \ddagger$ & 1.29 & $0.87,1.93$ \\
\hline & & & \multirow[t]{6}{*}{$\begin{array}{l}8585 / 350 \text { (Women) } \\
\text { Nurses' Health Study }\end{array}$} & \multirow[t]{6}{*}{8} & $\begin{array}{l}\text { Whole milk (one } 8 \text { ounce glass: almost never } \\
\qquad v \text {. }>\text { one per d) }\end{array}$ & 1.46 & $0.82,2.57$ \\
\hline & & & & & $\begin{array}{l}\text { Skimmed milk (one } 8 \text { ounce glass: almost never } \\
\quad v \text {. }>\text { one per d) }\end{array}$ & 0.87 & $0.50,1.50$ \\
\hline & & & & & Fermented dairy products $(10 v .134 \mathrm{~g} / \mathrm{d})$ & 0.87 & $0.62,1 \cdot 23$ \\
\hline & & & & & $\begin{array}{l}\text { Hard cheese ( } 1 \text { ounce serving: < three per month } \\
\quad v .>\text { one per d) }\end{array}$ & 0.91 & $0.45,1.83$ \\
\hline & & & & & Total Ca intake $(388$ v. $1232 \mathrm{mg} / \mathrm{d})$ & $1 \cdot 17$ & $0.81,1.69$ \\
\hline & & & & & Dietary vitamin D (500 v. $909 \mathrm{IU} / \mathrm{d} ; 1980-88) \S$ & 0.68 & $0.41,1 \cdot 13$ \\
\hline Hyman et al. $(1998)^{(53)}$ & USA & $\begin{array}{l}\text { Adenoma } \\
\text { recurrence }\end{array}$ & $\begin{array}{l}\text { 709/260 } \\
\text { Antioxidant Polyp } \\
\text { Prevention Study }\end{array}$ & $1-4$ & Dietary Ca $(610$ v. $1044 \mathrm{mg} / \mathrm{d})$ & 0.72 & $0.43,1 \cdot 22$ \\
\hline Martinez et al. (2002) ${ }^{(54)}$ & USA & \multirow{2}{*}{$\begin{array}{l}\text { Adenoma } \\
\text { recurrence }\end{array}$} & $1304 / 365$ & \multirow[t]{2}{*}{3} & Total Ca intake (698 v. $1068 \mathrm{mg} / \mathrm{d})$ & $0.56(P=0.007$ for trend $)$ & $0.39,0.80$ \\
\hline \multirow{3}{*}{ Kesse et al. (2005) $)^{(36)}$} & \multirow{3}{*}{ France } & & $\begin{array}{l}\text { Wheat Bran Fiber Trial } \\
4804 / 516\end{array}$ & & $\begin{array}{l}\text { Vitamin } \mathrm{D}(<1.14 \mathrm{v} .>8.7 \mu \mathrm{g} / \mathrm{d}) \\
\text { Total } \mathrm{Ca}(<786 \mathrm{v} .>1226 \mathrm{mg} / \mathrm{d})\end{array}$ & $\begin{array}{l}0.78 \\
0.80(P=0.04 \text { for trend })\end{array}$ & $0.54,1 \cdot 13$ \\
\hline & & \multirow{2}{*}{$\begin{array}{l}\text { Adenoma } \\
\text { incidence }\end{array}$} & French E3N-EPIC & \multirow{2}{*}{7} & Dairy $\mathrm{Ca}(<371 \mathrm{v} .>755 \mathrm{mg} / \mathrm{d})$ & $0.86(P=0.04$ for trend $)$ & $0.67,1 \cdot 11$ \\
\hline & & & Prospective Study & & Vitamin $D(<1.73 v .>3.26 \mu \mathrm{g} / \mathrm{d})$ & $1 \cdot 15$ & $0.88,1.49$ \\
\hline \multirow[t]{4}{*}{ Hartman et al. $(2005)^{(55)}$} & \multirow[t]{4}{*}{ USA } & \multirow{4}{*}{$\begin{array}{l}\text { Adenoma } \\
\text { recurrence }\end{array}$} & $1905 / 754$ & \multirow[t]{4}{*}{4} & Total Ca $(<666$ v. $>1226 \mathrm{mg} / \mathrm{d})$ & 0.91 & $0.67,1.23$ \\
\hline & & & Polyp Prevention Trial & & Dietary $\mathrm{Ca}(<635 \mathrm{v} .>1048 \mathrm{mg} / \mathrm{d})$ & 0.86 & $0.62,1.18$ \\
\hline & & & & & Dietary vitamin $\mathrm{D}\left(<2.75 v_{.}>5.95 \mu \mathrm{g} / \mathrm{d}\right)$ & 0.93 & $0.69,1.25$ \\
\hline & & & & & Total vitamin $\mathrm{D}(<3.35 \mathrm{v} .>11.7 \mu \mathrm{g} / \mathrm{d})$ & $0.84(P=0.03$ for trend $)$ & $0.62,1.13$ \\
\hline \multirow[t]{2}{*}{ Oh et al. $(2007)^{(56)}$} & \multirow[t]{2}{*}{ USA } & \multirow[t]{2}{*}{$\begin{array}{l}\text { Distal adenoma } \\
\text { incidence }\end{array}$} & $\begin{array}{l}48115 / 2747 \\
\text { Nurses' Health Study }\end{array}$ & \multirow[t]{2}{*}{22} & Total Ca intake $(510$ v. $946 \mathrm{mg} / \mathrm{d})$ & $0.88(P=0.06$ for trend $)$ & $0.74,1.04$ \\
\hline & & & & & Total vitamin D intake $(107 \mathrm{v} .587 \mathrm{IU} / \mathrm{d}) \|$ & $0.79(P=0.07$ for trend $)$ & $0.63,0.99$ \\
\hline
\end{tabular}

RR, relative risk; EPIC, European Prospective Investigation into Cancer and Nutrition.

* 1 US fluid ounce $=29.57 \mathrm{ml} ; 8$ US fluid ounces $=237 \mathrm{ml} ; 1$ ounce serving $=28.35 \mathrm{~g}$ serving

† Adjusted RR for the highest dietary intake compared with the lowest dietary intake.

$\neq 118 \mathrm{v} .954 \mathrm{IU} / \mathrm{d}(<3.0 \mathrm{v} .>23.9 \mu \mathrm{g} / \mathrm{d})$.

$\S 500$ v. $909 \mathrm{IU} / \mathrm{d}(<12.5$ v. $>22.7 \mu \mathrm{g} / \mathrm{d})$

$\| 107$ v. $587 \mathrm{IU} / \mathrm{d}(<2.7 \mathrm{v} .>14.7 \mu \mathrm{g} / \mathrm{d})$. 
Kesse et al. ${ }^{(36)}$ found a trend of decreasing risk of adenoma with increasing $\mathrm{Ca}$ intake, although the RR for the highest v. the lowest quartiles of intake was not significant. An analysis of the baseline data on dietary intake and supplement use from the Polyp Prevention Trial showed that there was no association between $\mathrm{Ca}$ or dietary vitamin $\mathrm{D}$ intake and adenoma recurrence ${ }^{(55)}$, although there were inverse associations between $\mathrm{Ca}$ and vitamin $\mathrm{D}$ supplementation with both single and multiple adenoma recurrence. Oh et al. ${ }^{(56)}$ using data from the Nurses' Health Study showed that higher intakes of total $\mathrm{Ca}$ were associated with a reduced risk of distal colorectal adenoma.

Relatively few studies have reported dairy intakes (as opposed to $\mathrm{Ca}$ ) in relation to colorectal adenoma risk. A case-control study in a Japanese population has reported a protective effect on colorectal adenomas of high dairy intakes in conjunction with other healthy dietary patterns ${ }^{(57)}$. Data from the Health Professionals Follow-Up Study and the Nurses' Health Study showed that fermented dairy products and cheese were not associated with adenoma risk, even after adjusting for saturated fat intake ${ }^{(52)}$ and baseline data from the Polyp Prevention Trial showed that there was no association between the consumption of low- or high-fat dairy products and adenoma recurrence ${ }^{(55)}$. An early systematic review of eleven case-control and two cohort studies did not find an association between dairy intake and colorectal adenoma risk ${ }^{(58)}$.

\section{Vitamin D and colorectal cancer risk}

Animal studies have shown that dietary $\mathrm{Ca}$ and vitamin $\mathrm{D}$ status act synergistically to modify CRC risk $^{(59)}$. Vitamin D is an important component of dairy foods, and $\mathrm{Ca}$ and vitamin $\mathrm{D}$ are metabolically related since the absorption of $\mathrm{Ca}$ in the gut relies on adequate levels of vitamin D. Several prospective studies that have assessed total vitamin D intake and CRC or colorectal adenoma risk have reported non-significant inverse associations (see Tables 1 and 2), although in some studies total vitamin D intake was unrelated to risk $\mathrm{k}^{(37,52)}$. A few studies have reported a doseresponse effect ${ }^{(18,33,55)}$. However, these findings need to be interpreted with caution since dietary sources do not account for total vitamin D status; UV radiation induces vitamin $\mathrm{D}_{3}$ production in the skin, making sun exposure an important source of the vitamin ${ }^{(60)}$.

Intervention trials provide some evidence of benefit of high vitamin D intake on adenoma recurrence, although these studies have generally investigated $\mathrm{Ca}$ and vitamin $\mathrm{D}$ in combination. Hartman et al. ${ }^{(55)}$ found a reduced risk of adenoma and a significant trend in individuals from the Polyp Prevention Trial. Similarly Oh et al. ${ }^{(56)}$ also found a reduced risk of distal adenoma in women from the Nurses' Health Study, with $P=0.07$ for trend. Of further interest are studies of genetic variations in the vitamin $D$ receptor, such as the vitamin D receptor Fokl polymorphism, which have been related to the risk of $\mathrm{CRC}^{(61,62)}$. These studies offer independent evidence (free from the effects of confounding associated with the measurement of dietary intakes) that vitamin $\mathrm{D}$ is important for human CRC. There is some evidence of interaction between vitamin $\mathrm{D}$ receptor polymorphisms and the consumption of dairy products ${ }^{(63)}$,
$\mathrm{Ca}^{(50,61,64)}$ and vitamin $\mathrm{D}^{(65)}$ and the risk of colorectal adenoma or cancer in some, though not all ${ }^{(66)}$, studies. These important interactions between $\mathrm{Ca}$ and vitamin $\mathrm{D}$ highlight a limitation in the epidemiological studies that have investigated the dairy-CRC link; most have failed to take into account vitamin D status of the individuals taking part in the studies because of the difficulties in trying to estimate the contribution to vitamin D by sunlight ${ }^{(60)}$.

\section{Evidence from calcium supplementation trials}

Several prospective studies have shown that $\mathrm{Ca}$ supplements decrease the risk of $\mathrm{CRC}^{(21,22,32,33,37)}$. In the pooled analysis of ten cohort studies by Cho et al. ${ }^{(11)}$, the reduction in risk was greater when $\mathrm{Ca}$ from supplements was included in the analysis (RR 0.78 (95\% CI 0.69, 0.88) v. RR 0.86 (95\% CI $0.78,0.95)$ for $\mathrm{Ca}$ from food sources). Three prospective studies showed a decreased risk of adenoma recurrence with Ca supplements ${ }^{(53-55)}$. A meta-analysis ${ }^{(8)}$ on the studies by Martinez et al. ${ }^{(54)}$ and Hartman et al. ${ }^{(55)}$ gave a summary effect estimate of 0.91 (95\% CI 0.85, 0.98) per $200 \mathrm{mg} \mathrm{Ca} / \mathrm{d}$.

Randomised controlled trials have been conducted with both adenoma and $\mathrm{CRC}$ as endpoints. For colorectal adenoma, two trials showed a decreased risk of adenoma with $\mathrm{Ca}$ supplements. In the Calcium Polyp Prevention Study Group, Baron et al. ${ }^{(67)}$ showed that supplementation with $1200 \mathrm{mg} \mathrm{Ca} / \mathrm{d}$ for 4 years in 930 subjects with recently resected adenoma was associated with a $19 \%$ reduction in risk of adenoma recurrence ( $R R$ 0.81; $95 \%$ CI 0.67 , 0.99). A 5-year follow-up after the end of the intervention showed that subjects in the Ca group still had a significantly lower risk of adenoma than those in the placebo group (31.5 v. 43.2\%; adjusted RR 0.63 (95\% CI 0.46, 0.87); $P=0.005)^{(68)}$. However, follow-up for a further 5 years did not show any difference between the groups ${ }^{(68)}$. Bonithon-Kopp et al. (69) showed that supplementation with $2000 \mathrm{mg} \mathrm{Ca} / \mathrm{d}$ for 3 years also reduced adenoma recurrence in 665 subjects, although the effect was not significant (OR 0.66; $95 \%$ CI 0.38, 1.17). The results of both the above trials combined showed a significant reduction in adenoma recurrence with $\mathrm{Ca}$ supplementation (OR 0.74; $95 \%$ CI $0.58,0.95)^{(70)}$. In another 3-year intervention trial where $1600 \mathrm{mg} \mathrm{Ca}$ was given in conjunction with $\beta$-carotene $(15 \mathrm{mg})$, vitamin C (150 mg), vitamin E (75 mg) and Se $(101 \mu \mathrm{g})$ there was no effect on the growth of preexisting adenomas, although there was a non-significant reduced risk of new adenoma growth in subjects $<60$ years of age (mean difference $2.3 \mathrm{~mm} ; 95 \%$ CI 0.26, 4.36) ${ }^{(71)}$.

A recent intervention trial involving 36282 postmenopausal women participating in the Women's Health Initiative showed that $1000 \mathrm{mg}$ elemental $\mathrm{Ca} / \mathrm{d}$ (as calcium carbonate) in conjunction with $10 \mu \mathrm{g}$ (400 IU) vitamin D for 7 years had no effect on the incidence of $\mathrm{CRC}^{(72)}$. Overall this was a good-quality study, loss to follow-up was minimal (data were available on $97 \%$ of living participants) and adherence to the intervention was relatively good $(70 \%$ of women took $\geq 50 \%$ of their study medication through the 6th year). Serum concentrations of vitamin D at baseline and additional use of $\mathrm{Ca}$ and vitamin $\mathrm{D}$ supplements by a subgroup of participants did not modify the effect of the intervention on the outcome. However, baseline 
$\mathrm{Ca}$ and vitamin D intakes (1151 mg/d and 9.1 $\mu \mathrm{g}$ (367 IU), respectively) were relatively high in this population. This may explain the lack of effect, particularly since pooled data from prospective studies suggest no further effect on CRC risk of $\mathrm{Ca}$ beyond this level of intake ${ }^{(11)}$; this is in contrast to intervention trials with adenoma recurrence as an endpoint, in which intakes $>1000 \mathrm{mg} / \mathrm{d}$ reduced the risk of colorectal adenoma $^{(70)}$. Another explanation for the lack of effect could be the duration of the intervention and the short follow-up period; CRC takes 10-20 years to develop so a follow-up period longer than 7 years may be necessary to detect any beneficial effects of Ca supplements on CRC risk.

\section{Potential chemopreventive agents in dairy foods}

Although $\mathrm{Ca}$ has been the main component in dairy products to be investigated for its protective role in CRC, dairy products contain many potential chemopreventive components such as vitamin $\mathrm{D}$, butyric acid, conjugated linoleic acid (CLA), sphingolipids, and probiotic bacteria in fermented products such as yoghurt ${ }^{(15)}$. The following section will present a brief review of the proposed mechanisms and evidence for them.

Ca may provide protection against CRC through two mechanisms. In the colon, Ca sequesters secondary bile acids such as deoxycholic acid (a by-product of fat metabolism) ${ }^{(73)}$ and phospholipids, both of which promote colorectal tumours in animal models, possibly by increasing bacterial production of diacylglycerol. Diacylglycerol is the second messenger for protein kinase $\mathrm{C}$, a key enzyme involved in signal transduction, which stimulates cell proliferation ${ }^{(74)}$. $\mathrm{Ca}$ has also been suggested to act directly on the colonic epithelium to inhibit the proliferation of epithelial cells by inducing differentiation and increasing apoptosis ${ }^{(75)}$, both of which are important processes for eliminating cancerous cells in the colon. $\mathrm{Ca}$ has been shown to decrease cell proliferation when added in high concentrations to human colonic epithelial cells cultured in vitro ${ }^{(76)}$.

Early studies in human subjects suggested a reduction in colonic epithelial cell proliferation with increasing $\mathrm{Ca}$ intake ${ }^{(76-78)}$, although these studies had small sample sizes. Subsequent studies showed that Ca supplementation did not reduce epithelial cell proliferation in the rectal mucosa of subjects with adenoma ${ }^{(79-81)}$, ulcerative colitis ${ }^{(82)}$ or hereditary non-polyposis $\mathrm{CRC}^{(83)}$, although Holt et al. ${ }^{(84)}$ showed that increasing $\mathrm{Ca}$ intake from dairy products in seventy individuals with previously resected colonic adenomas changed colonic biomarkers of cancer risk (proliferative activity of colonic epithelial cells and markers of normal cellular differentiation) towards normal. One study has shown that supplementation of the diet with $\mathrm{Ca}$ tablets or low-fat dairy foods lowered colonic epithelial cell proliferation $^{(85)}$. Generally, however, the weight of the evidence suggests that $\mathrm{Ca}$ supplements do not lower epithelial cell proliferation rates.

Animal studies have shown that dietary $\mathrm{Ca}$ and vitamin D status act synergistically to modify CRC risk ${ }^{(59)}$. Vitamin D may regulate the production of growth factors and cytokines, which are important for normal cell function, and also influence apoptosis and differentiation ${ }^{(59)}$. These effects act in unison and may inhibit uncontrolled cell growth. Studies in cell lines ${ }^{(86)}$ and animals ${ }^{(87)}$ have shown growth inhibition of tumour cells following administration of vitamin D. In animal studies, adequate vitamin D supply has been shown to prevent the hyperproliferation and adenoma formation induced by stress diet (high fat, low $\mathrm{Ca}$, high phosphate and low vitamin D) or carcinogen treatment (azoxymethane or 1,2-dimethylhydrazine). Human studies have shown that administration of vitamin $\mathrm{D}$ (in combination with $\mathrm{Ca}$ ) resulted in decreased proliferative indices and other markers of tumour growth in rectal mucosa of individuals with adenoma ${ }^{(88)}$. Increased levels of the circulating form of vitamin $\mathrm{D}$ (25-hydroxyvitamin $\mathrm{D}_{3}$ ) in the serum were significantly correlated with several independent indices of cell proliferation ${ }^{(89)}$. It is possible that vitamin D may be important in determining the effect of $\mathrm{Ca}$ on cell proliferation, and failure to account for vitamin D status may be partly responsible for the discrepancies between Ca supplementation studies with cell proliferation as an endpoint.

Apart from $\mathrm{Ca}$ and vitamin $\mathrm{D}$, other potential chemopreventive agents in dairy products have received more limited attention. Dietary butyric acid, found in the lipid fraction of milk and milk products, has been suggested to play a role in colorectal neoplasia. Butyric acid has been shown to inhibit proliferation and induce differentiation in tumour cell lines ${ }^{(90)}$ and animal studies ${ }^{(91)}$. However, it is more likely that these effects are a result of butyric acid production in the colon as a result of fermentation of dietary fibre by colonic microflora ${ }^{(92)}$, since dietary butyric acid is rapidly absorbed in the small bowel and metabolised in the liver and therefore never reaches the colon ${ }^{(93)}$

More convincing evidence exists for CLA ${ }^{(94)}$, a naturally occurring fatty acid present in dairy and beef products. CLA is derived from linoleic acid, a PUFA that is converted to CLA by bacteria in the rumen of ruminant animals ${ }^{(95)}$. Studies in cell lines have shown that CLA inhibits the growth of a variety of tumour cells ${ }^{(95-97)}$. Dietary CLA has also been shown to reduce colon cancer incidence in animals administered a colorectal carcinogen ${ }^{(98)}$. In a human epidemiological study in which CLA intakes were estimated, high CLA intakes were associated with a reduced risk of CRC; the RR associated with the highest $v$. the lowest quartile of intake was 0.71 (95\% CI $0.55,0.91 ; P$ for trend $=0.004)^{(99)}$. CLA may protect against cancer by inhibiting cell proliferation, modifying the fluidity of cell membranes, decreasing the production of prostaglandins (inflammatory mediators) and also stimulating the immune response $^{(93)}$.

Bacteria in fermented dairy products such as yoghurt may also have benefits for colonic health. Some strains of Bifidobacteria have been shown to reduce the formation of precursor lesions for CRC (for example, aberrant crypt foci) ${ }^{(100,101)}$. Studies on cell lines have shown that lactic acid bacteria can bind carcinogens present in cooked foods to their cell-wall skeletons ${ }^{(102)}$ and animal studies have shown the prevention of heterocyclic amine-induced DNA damage in the colon and liver of rats by different lactobacillus strains ${ }^{(103)}$. A study in human subjects has shown that the consumption of Lactobacillus acidophilus significantly reduced the excretion of carcinogens that had been ingested from heavily browned or burnt meat cooked at 
high temperature ${ }^{(104)}$. Bacteria in yoghurt and other fermented dairy products may also be capable of stimulating the immune system; mice fed milk containing L. bulgaricus or $L$. case $i$ had increased production of immune cells such as lymphocytes and macrophages ${ }^{(105)}$. However, other studies have shown more ambivalent results; administration of lactic acid bacteria to carcinogen-treated rats had no effect on tumour growth ${ }^{(106)}$ and some strains of lactic acid bacteria induced DNA damage and increased the effects of reactive oxygen species-generating chemicals in human colonic cells in vitro ${ }^{(107)}$.

Other components of milk that may have beneficial properties include sphingolipids such as sphingomyelin, which is a potent inhibitor of cell growth and also induces differentiation and apoptosis ${ }^{(108)}$. Dietary sphingomyelin fed in amounts that can be found in dairy products has been shown to inhibit aberrant crypt foci formation and decrease the proportion of malignant tumours in mice ${ }^{(109)}$. Another category of sphingolipids known as glycosphyngolipids were also shown to inhibit the formation of aberrant crypts by up to $60 \%$ in mice treated with a colorectal carcinogen ${ }^{(110)}$. Other compounds that may have beneficial effects include lactoferrin ${ }^{(111)}$ and the milk protein casein $^{(112)}$, although the evidence for these is limited.

\section{Conclusions}

Generally, individual studies looking at dairy intake in relation to CRC risk have reported non-significant inverse associations, although the pooling of data from these studies shows a significant protective effect. Ca has been the main component in dairy products to be investigated. However, it is currently difficult to translate the evidence into effective public health recommendations, since the $\mathrm{Ca}$ dose at which protection is maximised differs between studies from less than $1000 \mathrm{mg} / \mathrm{d}^{(33)}$ to $1400 \mathrm{mg} / \mathrm{d}^{(38)}$. This issue needs to be resolved, particularly as there are concerns that high dietary $\mathrm{Ca}$ intake may be a risk factor for advanced prostate cancer ${ }^{(40,113)}$. Apart from $\mathrm{Ca}$, components such as vitamin $\mathrm{D}$, dairy proteins, sphingolipids, CLA and probiotic bacteria in fermented dairy foods may also have beneficial effects, although most of the evidence for these comes from animal studies that have yet to be replicated in human subjects. The evidence for a protective role in CRC is strongest for milk, although the effect is evident from pooled data rather than individual cohort studies, which are generally nonsignificant. The limited evidence that hard cheese may increase CRC risk despite its high Ca content highlights the difficulties associated with trying to determine risk posed by a complex food group where an interplay of protective and harmful factors coexist.

\section{Acknowledgements}

The UK Dairy Council provided funding towards the present review.

I declare no conflicts of interest.

\section{References}

1. Cancer Research UK (2006) CancerStats. Mortality - UK. http://info.cancerresearchuk.org/images/pdfs/cs_mortality_ sept_2005.pdf

2. International Agency for Research on Cancer (2002) GLOBOCAN. Cancer Incidence, Mortality and Prevalence Worldwide (2002 estimates). http://www-dep.iarc.fr/GLOBOCAN_frame.htm

3. Stemmermann GN, Mandel M \& Mower HF (1979) Colon cancer: its precursors and companions in Hawaii Japanese. Natl Cancer Inst Monogr 53, 175-179.

4. Midgley R \& Kerr D (1999) Colorectal cancer. Lancet 353, 391-399.

5. Scholefield J (2000) ABC of colorectal cancer: screening. BMJ 321, 1004-1006.

6. Cannon-Albright LA, Skolnick MH, Bishop DT, Lee RG \& Burt RW (1988) Common inheritance of susceptibility to colonic adenomatous polyps and associated colorectal cancers. New Engl J Med 319, 533-537.

7. Platz EA, Willett WC, Colditz GA, Rimm EB, Spiegelman D \& Giovannucci E (2000) Proportion of colon cancer risk that might be preventable in a cohort of middle-aged US men. Cancer Causes Control 11, 579-588.

8. World Cancer Research Fund \& American Institute for Cancer Research (2007) Food, Nutrition, Physical Activity, and the Prevention of Cancer: a Global Perspective. Washington, DC: American Institute for Cancer Research.

9. Willett WC, Stampfer MJ, Colditz GA, Rosner BA \& Speizer FE (1990) Relation of meat, fat and fiber intake to the risk of colon cancer in a prospective study among women. New Engl J Med 323, 1664-1672.

10. Giovannucci E, Stampfer MJ, Colditz G, Rimm EB \& Willett WC (1992) Relationship of diet to risk of colorectal adenoma in men. J Natl Cancer Inst 84, 91-98.

11. Cho E, Smith-Warner SA, Spiegelman D, et al. (2004) Dairy foods, calcium, and colorectal cancer: a pooled analysis of 10 cohort studies. J Natl Cancer Inst 96, 1015-1022.

12. Park SY, Murphy SP, Wilkens LR, Nomura AM, Henderson BE \& Kolonel LN (2007) Calcium and vitamin D intake and risk of colorectal cancer: the Multiethnic Cohort Study. Am J Epidemiol 165, 784-793.

13. Henderson N, Gregory J, Irving K \& Swan G (2003) The National Diet and Nutrition Survey: adults aged 19 to 64 years, vol. 2. Energy protein, carbohydrate, fat and alcohol intake. http://www.statistics.gov.uk/downloads/theme health/NDNS_V2.pdf

14. Henderson N, Gregory J, Irving K, Bates CJ, Prentice A, Perks J, Swan G \& Farron M (2003) The National Diet and Nutrition Survey: adults aged 19 to 64 years, vol. 3. Vitamin and mineral intake and urinary analytes. http://www.food. gov.uk/multimedia/pdfs/ndnsv3.pdf

15. Norat T \& Riboli E (2003) Dairy products and colorectal cancer. A review of possible mechanisms and epidemiological evidence. Eur J Clin Nutr 57, 1-17.

16. Phillips RL (1975) Role of life-style and dietary habits in risk of cancer among Seventh-Day Adventists. Cancer Res 35, 3513-3522.

17. Phillips RL \& Snowdon DA (1985) Dietary relationships with fatal colorectal cancer among Seventh-Day Adventists. J Natl Cancer Inst 74, 307-317.

18. Garland C, Shekelle RB, Barrett Connor E, Criqui MH, Rossof AH \& Paul O (1985) Dietary vitamin D and calcium and risk of colorectal cancer: a 19-year prospective study in men. Lancet i, 307-309. 
19. Ursin G, Bjelke E, Heuch I \& Vollset SE (1990) Milk consumption and cancer incidence: a Norwegian prospective study. Br J Cancer 61, 454-459.

20. Thun MJ, Calle EE, Namboodiri MM, Flanders WD, Coates RJ, Byers T, Boffetta P, Garfinkel L \& Heath CW Jr (1992) Risk factors for fatal colon cancer in a large prospective study. J Natl Cancer Inst 84, 1491-1500.

21. Bostick RM, Potter JD, Sellers TA, McKenzie DR, Kushi LH \& Folsom AR (1993) Relation of calcium, vitamin D, and dairy food intake to incidence of colon cancer among older women. The Iowa Women's Health Study. Am J Epidemiol 137, 1302-1317.

22. Kampman E, Goldbohm A, van den Brandt PA \& van't Veer P (1994) Fermented dairy products, calcium, and colorectal cancer in The Netherlands Cohort Study. Cancer Res 54, 3186-3190.

23. Kearney J, Giovannucci E, Rimm EB, Ascherio A, Stampfer MJ, Colditz GA, Wing A, Kampman E \& Willett WC (1996) Calcium, vitamin D, and dairy foods and the occurrence of colon cancer in men. Am J Epidemiol 143, 907-917.

24. Martinez ME, Giovannucci EL, Colditz GA, Stampfer MJ, Hunter DJ, Speizer FE, Wing A \& Willett WC (1996) Calcium, vitamin D and the occurrence of colorectal cancer among women. J Natl Cancer Inst 88, 1375-1382.

25. Kato I, Akhmedkhanov A, Koenig K, Toniolo PG, Shore RE \& Riboli E (1997) Prospective study of diet and female colorectal cancer: the New York University Women's Health Study. Nutr Cancer 28, 276-281.

26. Hsing AW, McLaughlin JK, Chow WH, Schuman LM, Co Chien HT, Gridley G, Bjelke E, Wacholder S \& Blot W (1998) Risk factors for colorectal cancer in a prospective study among U.S. white men. Int J Cancer 77, 549-553.

27. Singh PN \& Fraser GE (1998) Dietary risk factors for colon cancer in a low risk population. Am J Epidemiol 148, $761-774$

28. Zheng W, Anderson KE, Kushi LH, Sellers TA, Greenstein J, Hong CP, Cerhan JR, Bostick RM \& Folsom AR (1998) A prospective cohort study of intake of calcium, vitamin D and other micronutrients in relation to incidence of rectal cancer among postmenopausal women. Cancer Epidemiol Biomarkers Prev 7, 221-225.

29. Pietinen P, Malila N, Virtanen M, Hartman TJ, Tangrea JA, Albanes D \& Virtamo J (1999) Diet and risk of colorectal cancer in a cohort of Finnish men. Cancer Causes Control 10, 387-396.

30. Jarvinen R, Knekt P, Hakulinen T \& Aromaa A (2001) Prospective study on milk products, calcium and cancers of the colon and rectum. Eur J Clin Nutr 55, 1000-1007.

31. Terry P, Baron JA, Bergkvist L, Holmberg L \& Wolk A (2002) Dietary calcium and vitamin D intake and risk of colorectal cancer: a prospective cohort study in women. Nutr Cancer 43, 39-46.

32. Wu K, Willett WC, Fuchs CS, Colditz GA \& Giovannucci EL (2002) Calcium intake and risk of colon cancer in women and men. J Natl Cancer Inst 94, 437-446.

33. McCullough ML, Robertson AS, Rodriguez C, Jacobs EJ, Chao A, Carolyn J, Calle EE, Willett WC \& Thun MJ (2003) Calcium, vitamin D, dairy products, and risk of colorectal cancer in the Cancer Prevention Study II Nutrition Cohort (United States). Cancer Causes Control 14, $1-12$.

34. Sanjoaquin MA, Appleby PN, Thorogood M, Mann JI \& Key TJ (2004) Nutrition, lifestyle and colorectal cancer incidence: a prospective investigation of 10998 vegetarians and non-vegetarians in the United Kingdom. Br J Cancer 90, $118-121$.
35. Flood A, Peters U, Chatterjee N, Lacey JV Jr, Schairer C \& Schatzkin A (2005) Calcium from diet and supplements is associated with reduced risk of colorectal cancer in a prospective cohort of women. Cancer Epidemiol Biomarkers Prev 14, 126-132.

36. Kesse E, Boutron-Ruault MC, Norat T, Riboli E \& ClavelChapelon F (2005) Dietary calcium, phosphorus, vitamin D, dairy products and the risk of colorectal adenoma and cancer among French women of the E3N-EPIC prospective study. Int J Cancer 117, 137-144.

37. Lin J, Zhang SM, Cook NR, Manson JE, Lee IM \& Buring JE (2005) Intakes of calcium and vitamin D and risk of colorectal cancer in women. Am J Epidemiol 161, 755-764.

38. Larsson SC, Bergkvist L, Rutegård J, Giovannucci E \& Wolk A (2006) Calcium and dairy food intakes are inversely associated with colorectal cancer risk in the Cohort of Swedish Men. Am J Clin Nutr 83, 667-673.

39. Shin A, Li H, Shu XO, Yang G, Gao YT \& Zheng W (2006) Dietary intake of calcium, fiber and other micronutrients in relation to colorectal cancer risk: results from the Shanghai Women's Health Study. Int J Cancer 119, 2938-2942.

40. Gallus S, Bravi F, Talamini R, Negri E, Montella M, Ramazzotti V, Franceschi S, Giacosa A \& La Vecchia C (2006) Milk, dairy products and cancer risk (Italy). Cancer Causes Control 17, 429-437.

41. Kiunga GA, Raju J, Sabljic N, Bajaj G, Good CK \& Bird RP (2004) Elevated insulin receptor protein expression in experimentally induced colonic tumors. Cancer Lett 211, $145-153$.

42. Giugliano D, Ceriello A \& Esposito K (2006) The effects of diet on inflammation: emphasis on the metabolic syndrome. $J$ Am Coll Cardiol 48, 677-685.

43. Food Standards Agency (2002) McCance \& Widdowson's The Composition of Food, 6th summary ed. Cambridge: Royal Society of Chemistry.

44. Bergsma-Kadijk JA, van't Veer P, Kampman E \& Burema J (1996) Calcium does not protect against colorectal neoplasia. Epidemiology 7, 590-597.

45. Weinberg LG, Berner LA \& Groves JE (2004) Nutrient contributions of dairy foods in the United States, Continuing Survey of Food Intakes by Individuals, 1994-1996, 1998. J Am Diet Assoc 104, 895-902.

46. Martinez ME, McPherson RS, Annegers JF \& Levin B (1996) Association of diet and colorectal adenomatous polyps: dietary fiber, calcium, and total fat. Epidemiology 7, 264-268.

47. Tseng M, Murray SC, Kupper LL \& Sandler RS (1996) Micronutrients and the risk of colorectal adenomas. Am J Epidemiol 144, 1005-1014.

48. Morimoto LM, Newcomb PA, Ulrich CM, Bostick RM, Lais CJ \& Potter JD (2002) Risk factors for hyperplastic and adenomatous polyps: evidence for malignant potential. Cancer Epidemiol Biomarkers Prev 11, 1012-1018.

49. Peters U, McGlynn KA, Chatterjee N, Gunter E, GarciaClosas M, Rothman N \& Sinha R (2001) Vitamin D, calcium, and vitamin $\mathrm{D}$ receptor polymorphism in colorectal adenomas. Cancer Epidemiol Biomarkers Prev 10, $1267-1274$

50. Peters U, Chatterjee N, McGlynn KA, Schoen RE, Church TR, Bresalier RS, Gaudet MM, Flood A, Schatzkin A \& Hayes RB (2004) Calcium intake and colorectal adenoma in a US colorectal cancer early detection program. Am J Clin Nutr 80, 1358-1365.

51. Miller EA, Keku TO, Satia JA, Martin CF, Galanko JA \& Sandler RS (2007) Calcium, dietary, and lifestyle factors in the prevention of colorectal adenomas. Cancer 109, $510-517$. 
52. Kampman E, Giovannucci E, van't Veer P, Rimm E, Stampfer MJ, Colditz GA, Kok FJ \& Willett WC (1994) Calcium, vitamin D, dairy foods, and the occurrence of colorectal adenomas among men and women in two prospective studies. Am J Epidemiol 139, 16-29.

53. Hyman J, Baron JA, Dain BJ, Sandler RS, Haile RW, Mandel JS, Mott LA \& Greenberg ER (1998) Dietary and supplemental calcium and the recurrence of colorectal adenomas. Cancer Epidemiol Biomarkers Prev 7, 291-295.

54. Martinez ME, Marshall JR, Sampliner R, Wilkinson J \& Alberts DS (2002) Calcium, vitamin D, and risk of adenoma recurrence (United States). Cancer Causes Control 13, 213-220.

55. Hartman TJ, Albert PS, Snyder K, et al. (2005) Polyp Prevention Study Group. The association of calcium and vitamin D with risk of colorectal adenomas. J Nutr 135, 252-259.

56. Oh K, Willett WC, Wu K, Fuchs CS \& Giovannucci E (2007) Calcium and vitamin D intakes in relation to risk of distal colorectal adenoma in women. Am J Epidemiol 165, $1178-1186$

57. Mizoue T, Yamaji T, Tabata S, Yamaguchi K, Shimizu E, Mineshita M, Ogawa S \& Kono S (2005) Dietary patterns and colorectal adenomas in Japanese men: the Self-Defense Forces Health Study. Am J Epidemiol 161, 338-345.

58. Yoon H, Benamouzig R, Little J, Francois-Collange M \& Tome D (2000) Systematic review of epidemiological studies on meat, dairy products and egg consumption and risk of colorectal adenomas. Eur J Cancer Prev 9, 151-164.

59. Harris DM \& Go VL (2004) Vitamin D and colon carcinogenesis. J Nutr 134, 3463S-3471S.

60. Millen AE \& Bodnar LM (2008) Vitamin D assessment in population-based studies: a review of the issues. Am J Clin Nutr 87, 1102S-1105S

61. Wong HL, Seow A, Arakawa K, Lee HP, Yu MC \& Ingles SA (2003) Vitamin D receptor start codon polymorphism and colorectal cancer risk: effect modification by dietary calcium and fat in Singapore Chinese. Carcinogenesis 24, $1091-1095$

62. Park K, Woo M, Nam JH \& Kim JC (2006) Start codon polymorphisms in the vitamin $\mathrm{D}$ receptor and colorectal cancer risk. Cancer Lett 237, 199-206.

63. Murtaugh MA, Sweeney C, Ma KN, Potter JD, Caan BJ, Wolff RK \& Slattery ML (2006) Vitamin D receptor gene polymorphisms, dietary promotion of insulin resistance, and colon and rectal cancer. Nutr Cancer 55, 35-43.

64. Slattery ML, Neuhausen SL, Hoffman M, Caan B, Curtin K, Ma KN \& Samowitz W (2004) Dietary calcium, vitamin D, VDR genotypes and colorectal cancer. Int J Cancer 111, 750-756.

65. Kim HS, Newcomb PA, Ulrich CM, Keener CL, Bigler J, Farin FM, Bostick RM \& Potter JD (2001) Vitamin D receptor polymorphism and the risk of colorectal adenomas: evidence of interaction with dietary vitamin D and calcium. Cancer Epidemiol Biomarkers Prev 10, 869-874.

66. Grau MV, Baron JA, Sandler RS, Haile RW, Beach ML, Church TR \& Heber D (2003) Vitamin D, calcium supplementation, and colorectal adenomas: results of a randomized trial. J Natl Cancer Inst 95, 1765-1771.

67. Baron JA, Beach M, Mandel JS, et al. (1999) Calcium supplements for the prevention of colorectal adenomas. Calcium Polyp Prevention Study Group. New Engl J Med 340, 101-107.

68. Grau MV, Baron JA, Sandler RS, et al. (2007) Prolonged effect of calcium supplementation on risk of colorectal adenomas in a randomized trial. J Natl Cancer Inst 99, $129-136$.
69. Bonithon-Kopp C, Kronborg O, Giacosa A, Rath U \& Faivre J (2000) Calcium and fibre supplementation in prevention of colorectal adenoma recurrence: a randomised intervention trial. Lancet 356, 1300-1306.

70. Weingarten MA, Zalmanovici A \& Yaphe J (2005) Dietary calcium supplementation for preventing colorectal cancer and adenomatous polyps. The Cochrane Database of Systematic Reviews 2005, issue 3, CD003548. http://mrw.interscience.wiley.com/cochrane/clsysrev/articles/CD003548/frame.html

71. Hofstad B, Almendingen K, Vatn M, Andersen SN, Owen RW, Larsen S \& Osnes M (1998) Growth and recurrence of colorectal polyps: a double-blind 3-year intervention with calcium and antioxidants. Digestion 59, 148-156.

72. Wactawski-Wende J, Kotchen JM, Anderson GL, et al. (2006) Calcium plus vitamin D supplementation and the risk of colorectal cancer. New Engl J Med 354, 684-696.

73. Govers MJ, Termont DS, Lapre JA, Kleibeuker JH, Vonk RJ \& van der Meer R (1996) Calcium in milk products precipitates intestinal fatty acids and secondary bile acids and thus inhibits colonic cytotoxicity in humans. Cancer Res 56, 3270-3275.

74. Holt PR, Moss SF, Whelan R, Guss J, Gilman J \& Lipkin M (1996) Fecal and rectal mucosal diacylglycerol concentrations and epithelial proliferative kinetics. Cancer Epidemiol Biomarkers Prev 5, 937-940.

75. Lipkin M \& Newmark H (1995) Calcium and the prevention of colon cancer. J Cell Biochem Suppl 22, 65-73.

76. Buset M, Lipkin M, Winawer S, Swaroop S \& Friedman E (1986) Inhibition of human colonic epithelial cell proliferation in vivo and in vitro by calcium. Cancer Res 46, 5426-5430.

77. Lipkin M \& Newmark H (1985) Effect of added dietary calcium on colonic epithelial-cell proliferation in subjects at high risk for familial colonic cancer. New Engl J Med 313, $1381-1384$.

78. Lipkin M, Friedman E, Winawer WS \& Newmark H (1989) Colonic epithelial proliferation in responders and nonresponders to supplemental dietary calcium. Cancer Res $\mathbf{4 9}$, 248-254.

79. Bostick RM, Potter JD, Fosdick L, Grambsch P, Lampe JW, Wood JR, Louis TA, Ganz R \& Grandits G (1993) Calcium and colorectal epithelial cell proliferation: a preliminary randomized, double-blinded, placebo-controlled clinical trial. J Natl Cancer Inst 85, 132-141.

80. Baron JA, Tosteson TD, Wargovich MJ, et al. (1995) Calcium supplementation and rectal mucosal proliferation: a randomized controlled trial. J Natl Cancer Inst 87, 1303-1307.

81. Alberts DS, Einspahr J, Ritenbaugh C, et al. (1997) The effect of wheat bran fiber and calcium supplementation on rectal mucosal proliferation rates in patients with resected adenomatous colorectal polyps. Cancer Epidemiol Biomarkers Prev 6, 161-169.

82. Bostick RM, Boldt M, Darif M, Wood JR, Overn P \& Potter JD (1997) Calcium and colorectal epithelial cell proliferation in ulcerative colitis. Cancer Epidemiol Biomarkers Prev 6, 1021-1027.

83. Cats A, Kleibeuker JH, van der Meer R, Kuipers F, Sluiter WJ, Hardonk MJ, Oremus ET, Mulder NH \& de Vries EG (1995) Randomized, double-blinded, placebo-controlled intervention study with supplemental calcium in families with hereditary nonpolyposis colorectal cancer. $J$ Natl Cancer Inst 87, 598-603.

84. Holt PR, Atillasoy EO, Gilman J, Guss J, Moss SF, Newmark H, Fan K, Yang K \& Lipkin M (1998) Modulation of abnormal colonic epithelial cell proliferation and 
differentiation by low-fat dairy foods: a randomized controlled trial. JAMA 280, 1074-1079.

85. Holt PR, Wolper C, Moss SF, Yang K \& Lipkin M (2001) Comparison of calcium supplementation or low-fat dairy foods on epithelial cell proliferation and differentiation. Nutr Cancer 41, 150-155.

86. Shabahang M, Buras RR, Davoodi F, Schumaker LM, Nauta RJ, Uskokovic MR, Brenner RV \& Evans SR (1994) Growth inhibition of HT-29 human colon cancer cells by analogues of 1,25-dihydroxyvitamin $\mathrm{D}_{3}$. Cancer Res 54, 4057-4064

87. Taniyama T, Wanibuchi H, Salim EI, Yano Y, Otani S, Nishizawa Y, Morii H \& Fukushima S (2000) Chemopreventive effect of 24R,25-dihydroxyvitamin $\mathrm{D}(3)$ in $N$, $N^{\prime}$-dimethylhydrazine-induced rat colon carcinogenesis. Carcinogenesis 21, 173-178.

88. Holt PR, Bresalier RS, Ma CK, Liu KF, Lipkin M, Byrd JC \& Yang K (2006) Calcium plus vitamin D alters preneoplastic features of colorectal adenomas and rectal mucosa. Cancer 106, 287-296.

89. Holt PR, Arber N, Halmos B, Forde K, Kissileff H, McGlynn KA, Moss SF, Kurihara N, Fan K, Yang K \& Lipkin M (2002) Colonic epithelial cell proliferation decreases with increasing levels of serum 25-hydroxy vitamin D. Cancer Epidemiol Biomarkers Prev 11, 113-119.

90. McBain JA, Eastman A, Nobel CS \& Mueller GC (1997) Apoptotic death in adenocarcinoma cell lines induced by butyrate and other histone deacetylase inhibitors. Biochem Pharmacol 53, 1357-1368.

91. Velazquez OC, Zhou D, Seto RW, Jabbar A, Choi J, Lederer HM \& Rombeau JL (1996) In vivo crypt surface hyperproliferation is decreased by butyrate and increased by deoxycholate in normal rat colon: associated in vivo effects on c-Fos and c-Jun expression. $J$ Parenter Enteral Nutr 20, 243-250.

92. Williams EA, Coxhead JM \& Mathers JC (2003) Anticancer effects of butyrate: use of micro-array technology to investigate mechanisms. Proc Nutr Soc 62, 107-115.

93. Parodi PW (1997) Cows' milk fat components as potential anticarcinogenic agents. J Nutr 127, 1055-1060.

94. MacDonald HB (2000) Conjugated linoleic acid and disease prevention: a review of current knowledge. J Am Coll Nutr 19, Suppl. 2, 111S-118S.

95. Maggiora M, Bologna M, Ceru MP, et al. (2004) An overview of the effect of linoleic acid and conjugated linoleic acid on the growth of several human tumour cell lines. Int J Cancer 112, 909-919.

96. Beppu F, Hosokawa M, Tanaka L, Kohno H, Tanaka T \& Miyashita K (2006) Potent inhibitory effect of trans9, trans 11 isomer of conjugated linoleic acid on the growth of human colon cancer cells. J Nutr Biochem 17, 830-836.

97. Bocca C, Bozzo F, Gabriel L \& Miglietta A (2006) Conjugated linoleic acid inhibits Caco-2 cell growth via ERK-MAPK signaling pathway. $J$ Nutr Biochem 18, 332-340.

98. Pak HS, Ryu JH, Ha YL \& Park JH (2001) Dietary conjugated linoleic acid (CLA) induces apoptosis of colonic mucosa in 1,2-dimethylhydrazine-treated rats: a possible mechanism of the anticarcinogenic effect by CLA. Br J Nutr 86, 549-555.
99. Larsson SC, Bergkvist L \& Wolk A (2005) High-fat dairy food and conjugated linoleic acid intakes in relation to colorectal cancer incidence in the Swedish Mammography Cohort. Am J Clin Nutr 82, 894-900.

100. Rowland IR, Rumney CJ, Coutts JT \& Lievense LC (1998) Effect of Bifidobacterium longum and inulin on gut bacterial metabolism and carcinogen-induced aberrant crypt foci in rats. Carcinogenesis (Lond) 19, 281-285.

101. Kulkarni N \& Reddy BS (1994) Inhibitory effect of Bifidobacterium longum cultures on the azoxymethaneinduced aberrant crypt foci formation and fecal bacterial $\beta$-glucuronidase. Proc Soc Experimental Biol Med 207, $278-283$.

102. Zhang XB \& Ohta Y (1993) Antimutagenicity of cell fractions of microorganisms on potent mutagenic pyrolysates. Mut Res 298, 247-253.

103. Zsivkovits M, Fekadu K, Sontag G, Nabinger U, Huber WW, Kundi M, Chakraborty A, Foissy H \& Knasmüller S (2003) Prevention of heterocyclic amine-induced DNA damage in colon and liver of rats by different lactobacillus strains. Carcinogenesis 24, 1913-1918.

104. Lidbeck A, Nord CE, Gustafsson JA \& Rafter J (1992) Lactobacilli, anticarcinogenic activities and human intestinal microflora. Eur J Cancer Prev 1, 341-353.

105. Perdigon G, Vintini E, Alvarez S, Medina M \& Medici M (1999) Study of the possible mechanisms involved in the mucosal immune system activation by lactic acid bacteria. $J$ Dairy Sci 82, 1108-1114.

106. Li W \& Li CB (2003) Lack of inhibitory effects of lactic acid bacteria on 1,2-dimethylhydrazine-induced colon tumors in rats. World J Gastroenterol 9, 2469-2473.

107. Koller VJ, Marian B, Stidl R, Nersesyan A, Simic T, Sontag G \& Knasmuller S (2008) Impact of lactic acid bacteria on oxidative DNA damage in human derived colon cells. Food Chem Toxicol 46, 1221-1229.

108. Merrill AH, Schmelz EM, Dillehay DL, Spiegel S, Shayman JA, Schroeder JJ, Riley RT, Voss KA \& Wang E (1997) Sphingolipids - the enigmatic lipid class: biochemistry, physiology and pathophysiology. Toxicol Appl Pharmacol 142, 208-225.

109. Dilehay DL, Webb SJ, Schmelz E-M \& Merrill AH Jr (1994) Dietary sphingomyelin inhibits 1,2-dimethylhydrazine-induced colon cancer in CF1 mice. J Nutr $\mathbf{1 2 4}$, 615-620.

110. Schmelz EM, Sullards MC, Dillehay DL \& Merrill AH Jr (2000) Colonic cell proliferation and aberrant crypt foci formation are inhibited by glycosphingolipids in 1,2dimethylhydrazine treated CF1 mice. J Nutr 130, 522-527.

111. Tsuda H, Sekine K, Ushida Y, Kuhara T, Takasuka N, Iigo M, Han BS \& Moore MA (2000) Milk and dairy products in cancer prevention: focus on bovine lactoferrin. Mut Res $\mathbf{4 6 2}$, 227-233.

112. van Boekel MA, Goeptar AR \& Alink GM (1997) Antimutagenic activity of casein against MNNG in the E. coli DNA repair host-mediated assay. Cancer Lett 114, 85-87.

113. Chan JM, Giovannucci E, Andersson SO, Yuen J, Adami HO \& Wolk A (1998) Dairy products, calcium, phosphorous, vitamin D, and risk of prostate cancer (Sweden). Cancer Causes Control 9, 559-566. 